\section{Insurers admit genetic discrimination}

Fears that the US insurance industry may discriminate against individuals who inherit certain genes have been fuelled by the results of an anonymous survey of the industry. Researchers in Buffalo, New York, queried the industry's attitudes to people carrying the gene for hereditary nonpolyposis colorectal cancer (HNPCC). The results, which provide clear evidence of discrimination, could put some members of the insurance industry on the wrong side of the law.

Manuel Rodriguez-Bigas, a surgeon at the Roswell Park Cancer Institute in Buffalo, reported the team's results at a recent meeting of the American Society of Clinical Oncology in Denver. He mailed 1000 questionnaires asking insurance companies in each of the 50 states of the US whether they would provide health, life and disability cover for carriers of the gene and their children. Only 77 surveys were returned from five companies who made their sentiments clear by sending back blank forms. From 49 replies concerning health insurance, five companies admitted that they would not insure a carrier of the HNPCC gene, and one said that it would not insure the carrier's relatives either. Of 46 responses concerning life insurance, two said that they would not underwrite either the HNPCC carrier or their children. Twelve companies indicated that they would only provide life insurance at an increased premium. The results were similar for disability insurance. Rodriguez-Bigas. the same legislative umbrella. the industry out of business.
Some companies explained their decision to refuse insurance by arguing that the costs of surveillance and treatment associated with HNPCC are too high carriers require repeated rectal examination and may also need surgery for polyp removal. Some 30 companies claimed they would finance more frequent examinations, but many of them stipulated conditions, such as limiting their contributions to $\$ 100$ per year. "This wouldn't even take you to first base," said

An increasing number of states have passed laws that make it illegal to decline health insurance on genetic grounds. But while the law appears to be tightening its grip on health insurance, life and disability coverage do not always come under

According to Harvey Raymond, a spokesperson for the Health Insurance Association of America, these classes of insurance are a major concern to the industry. Life and disability plans are purchased on a voluntary basis, with individuals choosing when and how much they want to buy. For this reason, Raymond says, the organisation is opposed to legislation that would restrict the industry's access to any type of data on a potential client be that genetic, medical or sociological. He claims that not knowing what the customer knows would ultimately put

Karen Birmingham

\section{Health funds slashed}

AUSTRALIA has made massive cuts to its health budget to save A $\$ 1.6$ billion (US\$1.24 billion) over the next four years. Almost half the savings will be made by restructuring the Pharmaceutical Benefits Scheme, which makes certain prescription drugs available to Australians at a subsidised rate. The government will reduce the subsidy on some of the most popular and expensive drugs in six groups listed under the scheme.These include medicines for the treatment of hypertension, gastric ulcers and depression, and cholesterollowering drugs. And, in an effort to encourage more people to pay for their New York

\section{Cloning research a possibility}

A special bioethics panel appointed by U.S. President Bill Clinton has called for the enactment of a tough new federal law in the United States that would ban the creation of a human being by cloning. But the commission left open the possibility that scientists could make cloned human embryos solely for research purposes.

Until the U.S. Congress passes such a law, the National Bioethics Advisory Commission recommended that the current prohibition on federally funded human cloning research be continued, and strongly urged the private sector to abide by the same restrictions. The panel chose not to ban all human cloning research, arguing that as long as the work does not result in a human being, tighter definition of the rules should await further consideration "We all need more time on this," said bioethicist Alexander Capron, a member of the commission. "The message is to keep thinking."

Clinton issued a moratorium in March after learning that British researcher Ian Wilmut and colleagues working in Edinburgh, Scotland, had successfully cloned a sheep they named Dolly. Clinton asked the panel to examine the moral and ethical dilemmas associated with the field and report back to him in the spring. The practical effect of the ban is moot, as there is no federally funded human cloning research currently underway in the United States.

At least one member of the U.S. Senate, Senator Christopher Bond (Republican, Missouri) already has said he wants to pass a federal law banning research that involves human cloning. "Creating human beings for our own purposes should be off limits to science," Bond said. It is not clear whether Congress has the authority under the U.S. constitution to outlaw private research, and any attempt could be met with a legal challenge. The report stressed that in the past, new attempts to exert "human control over nature" have been greeted with similar angst. But alarm often "gave way to cautious acceptance."

Various laws against human cloning already exist in Argentina, the UK, Denmark, Germany and Spain.

\section{Elizabeth BaN} Sydney
MaRlene Cimons Washington, D.C. 